\title{
PENGARUH PEMBERIAN DOSIS PROBIOTIK YANG BERBEDA PADAPAKAN KOMERSIL TERHADAP PERTUMBUHAN IKAN LELE DUMBO(Clariasgariepinus) PEMELIHARAAN PADAT TEBAR TINGGI
}

\author{
Setiawan Eka Putra', Endah Sri Redjeki ${ }^{2}$, Sa'idah Luthfiyah $^{2}$ \\ ${ }^{1}$ Mahasiswa Program Studi Akuakultur, Fakultas Pertanian Universitas Muhammadiyah Gresik. \\ ${ }^{2}$ Staf Pengajar FakultasPertanian Universitas Muhammadiyah Gresik. \\ E-mail : acong.putra69@gmail.com ; Phone : 085707998036
}

\begin{abstract}
African catfish (Clarias gariepinus) is one type of freshwater fish that has high economic value. African catfish with intensive cultivation are hampered by the high cost of feed that is not in accordance with the selling price of African catfish. An alternative effort that can be done is the addition of probiotics to feed which is expected to reduce feed costs. Probiotics are living microorganisms in fish culture that can prevent disease, thereby increasing production and can reduce economic losses. This study aims to analyze the effect of probiotics on the growth of absolute weight and daily growth rate of African catfish. The method used was Completely Randomized Design (RAL) with 4 treatments namely $0,2,4$ and $6 \mathrm{ml} / \mathrm{kg}$ of feed and repeated 3 times. Activities carried out in this study include preparation of containers, seed stocking, fish sampling, feed preparation, feeding and water management. The variables observed were absolute weight growth and daily growth rate. The results showed that the addition of probiotics to commercial feed significantly affected the growth of weight and daily growth rate of African catfish.
\end{abstract}

Keywords: African Catfish, Probiotics, Absolute Weight, Daily Growth Rate

\begin{abstract}
ABSTRAK
Ikan lele dumbo (Clarias gariepinus) merupakan salah satu jenis ikan air tawar yang memiliki nilai ekonomis tinggi. Ikan lele dumbo dengan budidaya intensif terhambat dengan tingginya biaya pakan yang tidak sesuai dengan harga jual ikan lele dumbo.Upaya alternatife yang dapat dilakukan yaitu penambahan probiotik pada pakan yang diharapkan dapat menekan biaya pakan.Probiotik adalah mikroorganisme hidupdalam budidaya ikan yang dapat mencegahpenyakit, sehingga meningkatkan produksidan dapat menurunkan kerugian ekonomi. Penelitian ini bertujuan untuk menganalisis pengaruh pemberian probiotik terhadap pertumbuhan bobot mutlak dan laju pertumbuhan harian ikan lele dumbo.Metode yang digunakan adalah Rancangan Acak Lengkap (RAL) dengan 4 perlakuan yaitu 0, 2, 4 dan $6 \mathrm{ml} / \mathrm{kg}$ pakan dan diulang sebanyak 3 kali. Kegiatan yang dilakukan dalam penelitian ini meliputipersiapan wadah, penebaran benih, sampling ikan, persiapan pakan, pemberian pakan dan pengelolaan air.Variabel yang diamati yaitu pertumbuhan bobot mutlak dan laju pertumbuhan harian. Hasil penelitian menunjukkan bahwa penambahan probiotik pada pakan komersil berpengaruh nyata terhadap pertumbuhan bobot dan laju pertumbuhan harian ikan lele dumbo.
\end{abstract}

Kata Kunci :Lele Dumbo, Probiotik,Bobot Mutlak, Laju Pertumbuhan Harian 


\section{PENDAHULUAN}

Meningkatnya minat konsumsi ikan dalam masyarakat harus diimbangi dengan penambahan jumlah hasil produksi perikanan. Hasil perikanan sebagian besar diperoleh dari kegiatan budidaya dan didukung oleh usaha penangkapan ikan dilaut maupun sungai. Sektor budidaya ikan air tawar memiliki potensi untuk dikembangkan terutama dalam usaha budidaya ikan lele. Kegiatan budidaya ikan lele saat ini sedang berkembang pesat di indonesia dalam memenuhi kebutuhan gizi maupun pangan. Budidaya ikan lele dumbo yang terkontrol dapat dilakukan dengan cara padat tebar yang tinggi. Padat tebar yang bisa digunakan dalam budidaya ikan lele sistem bioflok yaitu padat tebar maksimal 4.000 ekor $/ \mathrm{m}^{3}$ dan padat tebar optimal $2.000 \mathrm{ekor} / \mathrm{m}^{3}$ (Wiranata, 2016).Usaha budidaya intensif ini terkendala dengan tingginya harga pakan yang begitu mahal. Para pembudidaya ikan lele dumbo intensif pada akhirnya mencari solusi lain yang dapat mengurangi atau menekan biaya produksi untuk pakan, yakni salah satunya dengan menerapkan pemberian probiotik pada pakan.

Probiotik adalah mikroorganisme hidupdalam budidaya ikan yang dapat mencegahpenyakit, sehingga meningkatkan produksidan dapat menurunkan kerugian ekonomi (Elumalai, 2013). Pemberian probiotik dalam pakan merupakan salah satu alternatif untuk menghasilkan pakan yang dapat berfungsi ganda sehingga dapat menekan Rasio Konversi Pakan (FCR) dalam penggunaan pakan. Penelitian ini menggunakan probiotik komersil mengandung bakteri lactobacillus, acetobacter, dan yeast yang sangat efektif untuk budidaya ikan.Pada pembudidaya intensif dengan padat tebar yang tinggi sangat cocok digunakan karena dapat menekan biaya pakan dan mempercepat waktu panen.

Hasil penelitian Ahmadi (2012), tentang pemberian probiotik dalam pakan dengan dosis sebesar $6 \mathrm{ml} / \mathrm{kg}$ pakan menghasilkan laju pertumbuhan harian dan efisiensi pakan tertinggi yaitu $3,12 \%$ dan $31,65 \%$. Untuk itu masih perlu dilakukan penelitian lanjutan tentang dosis probiotik yang tepat sehingga dapat menentukan dosis terbaik yang bisa diaplikasikan dalam masyarakat.Sehingga hasil penelitian ini bertujuan untuk menganalisis pertumbuhan bobot mutlak dan laju pertumbuhan harian ikan lele dumbo (Clarias gariepinus).

\section{TINJAUAN PUSTAKA}

Ikan lele dumbo (Clarias gariepinus) merupakan ikan yang tidak bersisik sama sekali, kulitnya licin dan berlendir. Ikan lele dumbo memiliki alat pernapasan tambahan yang disebut arborescent organ terletak di bagian kepala dengan berwarna kemerahan penuh kapiler darah. Badan ikan lele dumbo (Clarias gariepinus) berbentuk memanjang dan memiliki tiga buah sirip tunggal yaitu, sirip punggung, sirip ekor, dan sirip dubur. Selain itu, Ikan lele dumbo juga memiliki dua pasang sirip yang berpasangan untuk alat bantu berenang, yaitu sirip dada dan sirip perut. Ikan lele dumbo (Clarias gariepinus) mempunyai senjata yang sangat ampuh dan berbisa berupa sepasang patil yang terletak di depan sirip dada (Najiyati, 2003).

Ikan lele dumbo jarang menampakkan aktivitasnya pada siang hari dan lebih menyukai tempat yang gelap, agak dalam, dan teduh. Hal ini bisa dimengerti karena ikan lele dumbo adalah binatang nokturnal, yaitu mempunyai kecenderungan beraktivitas dan mencari makan pada malam hari. Ikan lele dumbo juga termasuk ikan omnivora, yaitu pemakan segala jenis makanan tetapi cenderungpemakan daging atau karnivora.Pada kolam pemeliharaan budidaya secara intensif ikan lele dumbo dapat dibiasakan diberi pakan komersil pada pagi, sore atau malam hari.Pemberian pakan pada malam hari menunjukkan nafsu makan ikan lele dumbo lebih tinggi (Nuraeni, 2012). 
Probiotik raja lele merupakan mikroba probiotik isolat asli indonesia dengan kandungan bakteri lactobacillus sp.,Acetobacter sp., dan Yeast. Bakterilactobacillus sp berperan untuk menghasilkan enzim pencernaan seperti laktaseyang memanfaatkan karbohidrat diubah menjadi asam laktat. Bakteri Acetobacter sp berperan untuk menekan pertumbuhan bakteri pathogen di dalam usus, sedangkan yeast berperan memberikan aroma khas untuk meningkatkan nafsu makan ikan (Ramadhan, 2008). Jumlah bakteri yang terkandung pada probiotik raja lele sekitar 5,6 x $10^{8}$ koloni bakteri.Probiotik pada bidang akuakultur memainkan peran penting yang menentukan tingkat keberhasilan budidaya.Probiotik memiliki efekantimikrobial dan pada bidang akuakulturbertujuan untuk menjaga keseimbanganmikroba dan pengendalian patogen dalamsaluranpencernaan. Mikroorganisme padaprobiotik bersaing dengan patogen didalam saluran pencernaan untuk mencegahagar patogen tidak mengambil nutrisi yangdiperlukan untuk hidup ikan (Cruz, 2012).

\section{METODE PENELITIAN}

Penelitian dilaksanakan selama35 hari di Laboratorium Budidaya Perikanan Fakultas Pertanian berlokasikan di Universitas Muhammadiyah Gresik Jl. Sumatera No.101 Randuagung, Kabupaten Gresik, Propinsi Jawa Timur. Alat yang digunakan dalam penelitian ini adalah bak budidaya bundar 16 liter sebanyak 12 buah, timbangan digital, penggaris, serok ikan, baskom, pipet ukur, aerator, selang aerasi dan batu aerasi, serta alat pengukur kualitas air termometer, $\mathrm{pH}$ meter dan DO meter. Bahan yang digunakan benih ikan lele dumbo dengan ukuran rata-rata bobot $3 \mathrm{~g}$ dan panjang $7 \mathrm{~cm}$ diperoleh dari penjual benih di Desa Cerme Kidul Kecamatan Cerme Kabupaten Gresik, probiotik raja lele mengandung bakteri lactobacillus sp.,Acetobacter sp., dan Yeast, pakan pellet tipe 781-1, mollase dan Testkit sera Amonia.

Penelitian ini menggunakan Rancangan Acak Lengakap (RAL) dengan empat perlakuan dan tiga kali ulangan dengan susunan perlakuan sebagai berikut:

Perlakuan $\mathrm{P}_{0}$ :Ikan lele dumbo tanpa penambahan probiotik

PerlakuanP $\mathrm{P}_{1}$ : Ikan lele dumbo diberi tambahan probiotik dengan dosis $2 \mathrm{ml} / \mathrm{kg}$

PerlakuanP $\mathrm{P}_{2}$ : Ikan lele dumbo diberi tambahan probiotik dengan dosis $4 \mathrm{ml} / \mathrm{kg}$

PerlakuanP $\mathrm{P}_{3}$ : Ikan lele dumbo diberi tambahan probiotik dengan dosis $6 \mathrm{ml} / \mathrm{kg}$

Persiapan wadah pemeliharaan dimulai dari membersihkan bak penenilitan terlebih dahulu dicuci bersih kemudian dikeringkan setelah itu diisi air 10 liter dan ditata sesuai dengan susunan rancangan penelitian.Ikan uji sebelum ditebar diukur bobot dan panjang awal serta mengalami aklimatisasi terlebih dahulu terhadap kondisi kualitas air.Setelah itu sampling dilakukan secara berkala setiap seminggu sekali dengan mengambil beberapa ekor ikan.Dalam penelitian ini menggunakan padat tebar ikan lele dumbo dengan acuan dari sistem bioflok yaitu padat tebar 3 ekor/liter.Persiapan pakan pertama kali mengukur dosis probiotik setiap perlakuan setelah itu menimbang pakan pellet setiap perlakuan yang akan diberikan pada ikan. Selanjutnya dosis probiotik dicampurkan dengan 0,2 $\mathrm{ml}$ mollase dan ditambahkan air sebagai pengencer pada setiap perlakuan. Setelah probiotik dicampurkan dengan mollase disemprotkan pada pakan yang sudah ditimbang menggunakan semprotan air dan dikeringkan pada suhu 30 - 40 ${ }^{\circ} \mathrm{C}$. Pada saat kering pakan bisa diberikan pada ikan lele dumbo secara langsung sesuai kebutuhan 5\% dari bobot tubuh ikan. Pakan yang diberikan adalah pakan pellettipe 781- 
1 yang memilikikandungan protein 31\%-33\%. Pemberian pakan dilakukan setiap hari dengan frekuensi pemberian pakan sebanyak tiga kali dalam sehari yaitu pagi pukul 08.00 WIB, sore pukul 17.00 WIB dan malam pukul 21.00 WIB.Pengelolaan air bertujuan untuk menyediakan lingkungan hidup yang optimalsehingga diperoleh kelangsungan hidup dan pertumbuhan yang maksimum. Variabel yang diamati dalam penelitian ini meliputibobot mutlak dan laju pertumbuhan harian.

Perhitungan pertambahan bobot ikan dihitung berdasarkan rumus Effendie (1979) yaitu :

Keterangan:

$$
\text { Pertumbuhan bobot }=W t-W o
$$

Wt : Bobot ikan akhir pemeliharaan $(\mathrm{g})$

Wo : Bobot ikan awal pemeliharaan $(\mathrm{g})$

Laju pertumbuhan harian dapat dihitung dengan menggunakan rumus (Hariati, 1989):

$$
S G R=\frac{\operatorname{LnW} t-\operatorname{LnW} o}{t} \times 100 \%
$$

Keteranagan :

SGR :Laju pertumbuhan harian (\%)

Wt :Bobot rataan ikan dihari akhir pemeliharaan $(\mathrm{g})$

Wo :Bobot rataan ikan dihari awal perikanan $(\mathrm{g})$

t :Lama waktu pemeliharaan (s)

Datadianalisa mengunakan analisis sidik ragam (ANOVA) bertujuan untuk mengetahui pengaruh nyata perlakuan pada Uji F 5\%. Bila berbeda nyata maka dilakukan Uji BNT (Beda Nyata Terkecil) antara perlakuan dan variabel yang diamati serta dilanjut analisis polynomial orthogonal.

\section{HASIL DAN PEMBAHASAN}

\section{Hasil}

Berdasarkan penelitian yang telah dilakukandata di analisis menggunakan analisis sidik ragam (ANOVA) bertujuan untuk mengetahui pengaruh nyata perlakuan pada Uji F 5\%.Pada (Tabel 1) diketahui hasil analisis sidik ragam ANOVA pada nilai kuadrat tengah memberikan pengaruh sangat nyata pertumbuhan bobot mutlak dan laju pertumbuhan harian.Selanjutnya dilakukan Uji BNT (Beda Nyata Terkecil) dan analisis polynomial orthogonal.

Tabel 1. Nilai Kuadrat Tengah Analisis Sidik Ragam (ANOVA) Pada Variabel

\begin{tabular}{ccllll}
\hline Sumber Keragaman & $\mathrm{Db}$ & Bobot Mutlak & $\mathrm{SGR}$ & $\mathrm{F}_{\text {tabel }} 0,05$ & $\mathrm{~F}_{\text {tabel }} 0,01$ \\
\hline Perlakuan & 3 & $4.763^{* *}$ & $0.134^{* *}$ & 4.07 & 7.59 \\
Galat & 8 & 0.147 & 0.007 & & \\
Total & 11 & & & & \\
\hline
\end{tabular}

Keterangan : **) Menunjukkan berbeda sangat nyata berdasarkan uji $\mathrm{F}_{0,05}$ dan uji $\mathrm{F}_{0,01}$ 


\begin{tabular}{lcccc}
\hline \multirow{2}{*}{ Perlakuan } & \multicolumn{2}{c}{ Bobot Mutlak } & \multicolumn{2}{c}{ SGR } \\
\cline { 2 - 5 } & Rerata & Notasi & Rerata & Notasi \\
\hline $\mathrm{P}_{0}$ (kontrol) & 12.441 & $\mathrm{a}$ & 4.344 & $\mathrm{a}$ \\
$\mathrm{P}_{1}$ (Dosis 2 $\left.\mathrm{ml} / \mathrm{kg}\right)$ & 12.894 & $\mathrm{a}$ & 4.458 & $\mathrm{a}$ \\
$\mathrm{P}_{2}$ (Dosis 4 ml/kg) & 14.794 & $\mathrm{~b}$ & 4.765 & $\mathrm{~b}$ \\
$\mathrm{P}_{3}$ (Dosis 6 ml/kg) & 14.858 & $\mathrm{~b}$ & 4.751 & $\mathrm{~b}$ \\
BNT 5\% & 0.721 & & 0.161 & \\
\hline
\end{tabular}

Hasil uji BNT, Diketahui bahwa perlakuan dosis probiotik pada pakan memberikan nilai rerata dan notasi yang berbeda. Pada bobot mutlak dan laju pertumbuhan harian (SGR) perlakuan $\mathrm{P}_{3}$ dan $\mathrm{P}_{2}$ memiliki notasi yang sama namun berbeda dengan perlakuan $\mathrm{P}_{0}$ dan $\mathrm{P}_{1}$, artinya Perlakuan $\mathrm{P}_{2}$ dan $\mathrm{P}_{3}$ memberikan hasil yang terbaik pada variabel bobot mutlak dan SGR.

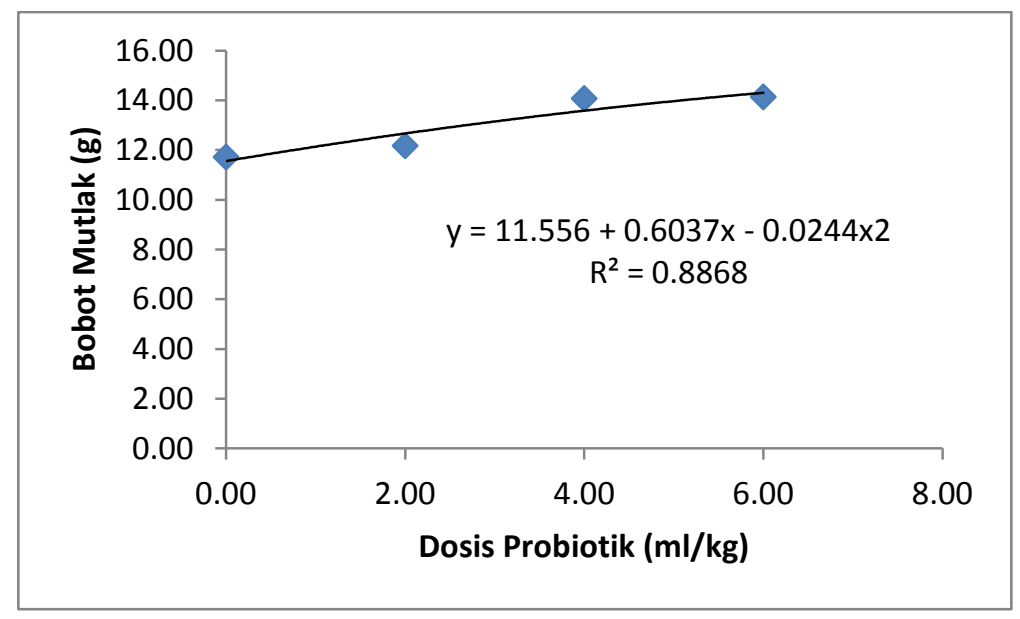

Gambar 1. Grafik polynomial orthogonal hubungan bobot mutlak ikan lele dumbo (Clarias gariepinus)dengan dosis probiotik

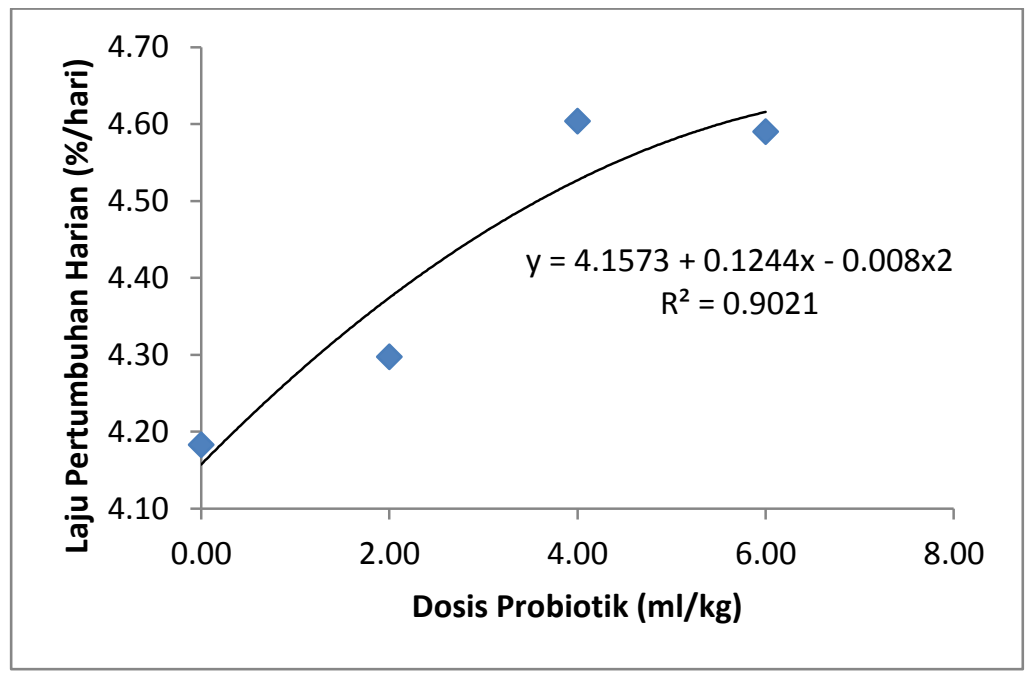

Gambar 2. Grafik polynomial orthogonal hubungan laju pertumbuhan harian ikan lele dumbo (Clarias gariepinus) dengan dosis probiotik

\section{Pembahasan}


Bobot Mutlak Ikan lele dumbo selamapenelititan berkisar 11,72 - 14,14 g, dengan perlakuan tertinggi didapatkan pada perlakuan $P_{3}$ penambahan dosis probiotik $6 \mathrm{ml} / \mathrm{kg}$ pakan sebesar 14,14 g sedangakan $\mathrm{P}_{0}$ (kontrol) sebesar 11,72 g. Hasil uji ANOVA pada Bobot Mutlak Ikan lele dumbo menunjukkan pemberian probiotik pada pakan memberikan perpedaan sangat nyata terhadap peningkatan bobot mutlak (g) $\left(\mathrm{F}_{\text {hit }}>\mathrm{F}_{\mathrm{tab}} 0,05\right)$. Selanjutnya dilakukan uji BNT menghasilkan nilai BNT 5\% sebesar 0,721. Pada perlakuan $\mathrm{P}_{3}$ memiliki notasi yang sama pada perlakuan $\mathrm{P}_{2}$ tetapi berbeda pada perlakuan $\mathrm{P}_{1}$ dan $\mathrm{P}_{0}$. Pertambahan bobot mutlak ikan lele dumbo dipengaruhi oleh pemberian pakan, Pakan yang diberikan adalah pakan pellet781-1 yang memilikikandungan protein 31\%-33\%. Hasil penelitian menunjukkan kisaran bobot mutlak selama penelitian ini adalah 11,72 - 14,14 g. Hasil tersebut lebih tinggi dibandingkan dengan penelitian sebelumnya dosis $6 \mathrm{ml} / \mathrm{kg}$ pakan menghasilkan bobot mutlak sebesar 13,78 g (Ahmadi, 2012). Pendapat Irianto (2007)bakteri pada probiotik mampu mengekresikan enzim-enzimpencernaan seperti protease danamilase sehingga mampumengoptimalkan daya cerna pakan.Pemberian pakan dengan protein tinggi berpengaruh terhadap aktivitas enzim pencernaan lipase, amilase dan protease pertumbuhan bobot ikan lele dumbo (Nurhayati, 2014).

Laju pertumbuhan harian ikan lele dumbo selama penelitian berkisar 4,18 $4,60 \% /$ hari, dengan perlakuan tertinggi $\mathrm{P}_{2}$ penambahan dosis probiotik $4 \mathrm{ml} / \mathrm{kg}$ pakan sebesar 4,60\% /hari. Hasisl uji ANOVA pada laju pertumbuhan harian ikan lele dumbo menunjukkan pemberian probiotik pada pakan memberikan perbedaan sangat nyata terhadap peningkatan laju pertumbuhan harian (SGR) $\left(\mathrm{F}_{\text {hit }}>\mathrm{F}_{\mathrm{tab}} 0,05\right)$. Sehingga dilakukan uji lanjut BNT mengahsilkan nilai BNT 5\% sebesar 0,161. Pada perlakuan $\mathrm{P}_{2}$ dan $\mathrm{P}_{3}$ memiliki notasi yang sama tetapi berbeda pada perlakuan $\mathrm{P}_{1}$ dan $\mathrm{P}_{0}$. sehinggapemberian dosis probiotik $4 \mathrm{ml} / \mathrm{kg}$ pakan lebih efisien dibandingkan dengan 6 $\mathrm{ml} / \mathrm{kg}$ pakan. Dikarenakan nilai jual ikan lele dumbo yang masih menurun dibandingkan dengan biaya produksi yang dikeluarkan masih tinggi oleh petani budidaya. Hasil penelitian menunjukkan kisaran laju pertumbuhan harian selama penelitian ini adalah 4,18 - 4,60\%/ hari. Hasil tersebut lebih tinggi dibandingkan dengan penelitian sebelumnya dosis $6 \mathrm{ml} / \mathrm{kg}$ pakan menghasilkan laju pertumbuhan harian sebesar 3,12\%/ hari (Ahmadi, 2012). Hal ini dapat diketahui bahwa probiotik dapat menyebabkan tingginya aktivitas bakteri pada saluran pencernaan dan perbedaan jumlah bakteri probiotik tersebut dapat mempengaruhi laju pertumbuhan ikan lele dumbo. Jumlah koloni bakteri probiotik dalam pakan menyebabkan aktivitas bakteri bekerja secara maksimal dalam pencernaan ikan. Sehingga daya cerna ikan menjadi lebih tinggi dalam menyerap sari - sari makanan dan menghasilkan pertumbuhan yang baik (Mulyadi, 2011).Bakteri Lactobacillus sp. dapat bekerja mengubah karbohidrat menjadi asam laktat, Lactobacillus sp. dapat meningkatkan keasaman sebesar 1,5-2,0\% pada subtrat. Dalam keadaan asam Lactobacillus sp. Memiliki kemampuan untuk menghambat bakteri pathogendan bakteri pembusuk (Rostini, 2007). Dimana probiotik raja lele memiliki kandungan bakteri lactobacillus sp.,Acetobacter sp., dan Yeast yang mampu mengekresikan enzim - enzim dalam pencernaan ikan lele dumbo. Salah satu faktor yang mempengaruhi keberhasilan produk probiotik dalam meningkatkan pertumbuhan dan efisiensi pakan pada ikan yaitu keberadaan bakteri probiotik pada saluran pencernaan (Irianto, 2003).

Analisis polynomial orthogonal pada pertumbuhan bobot mutlak dan laju pertumbuhan harian diketahui bahwa grafik polynomial menunjukkan garis linier sangat signifikan tetapi signifikan pada kubik. Pertumbuhan bobot mutlak ikan lele dumbo hasil analisis orthogonal polinomial ditunjukkan pada persamaan garis $\mathrm{Y}=11,556+$ $0,6307 x-0,0244 x^{2}$. Persamaan garis berbanding dengan pemberian dosis probiotik 
dimata titik persamaan dari dosis $0 \mathrm{ml} / \mathrm{kg}$ mengalami penurunan pada dosis $2 \mathrm{ml} / \mathrm{kg}$ dan mengalamai kenaikan pada dosis $4 \mathrm{ml} / \mathrm{kg}$ selanjuntnya turun kembali pada dosis 6 $\mathrm{ml} / \mathrm{kg}$. Hasil tersebut dapat diketahui bahwa pemberian dosis probiotik terhadap pertumbuhan bobot mtlak ikan lele dumbo pada dosis $4 \mathrm{ml} / \mathrm{kg}$ pakan yang terbaik, dengan nilai koefisien determinisasi sebesar 0,8868. Sedangkan pada laju pertumbuhan harian analisis orthogonal polinomial ditunjukkan pada persamaan garis $\mathrm{Y}=4,173+$ $0,1244 x-0,008 x^{2}$. Persamaan garis berbanding dengan pemberian dosis probiotik dimata titik persamaan dari dosis $0 \mathrm{ml} / \mathrm{kg}$ mengalami penurunan pada dosis $2 \mathrm{ml} / \mathrm{kg}$ dan mengalamai kenaikan pada dosis $4 \mathrm{ml} / \mathrm{kg}$ selanjuntnya turun kembali pada dosis 6 $\mathrm{ml} / \mathrm{kg}$. Hasil tersebut dapat diketahui bahwa pemberian dosis probiotik terhadap pertumbuhan bobot mtlak ikan lele dumbo pada dosis $4 \mathrm{ml} / \mathrm{kg}$ pakan yang terbaik, dengan nilai koefisien determinisasi sebesar 0,9021 . Nilai $\mathrm{R}^{2}$ adalah nilai koefisien determinasi yang mempunyai letak antara $0-1$, jika angkanya semakin mendekati 1 maka data tersebut semakin mendekati kebenaran (Widarjono, 2015).Sehingga pada dosis $4 \mathrm{ml} / \mathrm{kg}$ pakan dapat meningkatkan pertumbuhan bobot mutlak dan laju pertumbuhan harian sesuai dengan hasil uji orthogonal polynomial.Hasil tersebut dikarenakan pakan yang terkandung dalam probiotik mampu memicu pencernaan ikan sehingga ikan dapat tumbuh secara maksimal.Sehingga penambahan bobot ikan serta laju pertumbuhan ikan berbanding dengan pemberian pakan yang berkualitas baik dengan protein tinggi.Semakintinggi kandungan protein yang terdapatpada pakan, maka semakin baik ikanmengkonsumsi protein untukmemperoleh asam amino yang akandigunakan untuk pemeliharaan tubuh,reproduksi, dan pertumbuhan (Sopha, 2015).

\section{KESIMPULAN DAN SARAN}

Berdasarkan hasil penelitian yang telah dilakukan maka dapat diambil kesimpulan sebagai berikut :

1. Hasil notasi diketahui pada perlakuan $\mathrm{P}_{2}$ dosis $4 \mathrm{ml} / \mathrm{kg}$ dan $\mathrm{P}_{3}$ dosis $6 \mathrm{ml} / \mathrm{kg}$ memiliki nilai yang sama sehingga pemberain probiotik pada pakan $4-6 \mathrm{ml} / \mathrm{kg}$ menghasilkan pertumbuhan ikan lele dumbo terbaik.

2. Nilai pertumbuhan bobot mutlak terbaik didapatkan pada perlakuan $P_{3}$ dosis $6 \mathrm{ml} / \mathrm{kg}$ pakan dengan bobot mutlak sebesar $14,14 \mathrm{~g}$ sedangkan nilai laju pertumbuhan harian terbaik pada perlakuan $\mathrm{P}_{2}$ dosis $4 \mathrm{ml} / \mathrm{kg}$ pakan dengan nilai sebesar $4,60 \%$ / hari.

Maka dapatdisaran untuk memberikan dosis probiotik $4 \mathrm{ml} / \mathrm{kg}$ untuk penggunaan probiotik yang efisien.

\section{UCAPAN TERIMA KASIH}

Terima kasih disampaikan kepada segenap pihak yang telah membantu dalam pelaksaaan penelitianini terutama kepada Dosen pembimbing Ir. Endah Sri Redjeki, M.P,.M.Phil dan Sa'idah Lutfiyah, S.Pi,.MP serta Kaprodi Budidaya Perikanan dan seluruh Dosen Program Studi Budidaya Perikanan. Teman-teman Program Studi Budidaya Perikanan terutama teman-teman angkatan 2014 yang telah banyak membantu baik material maupun spiritual.

\section{DAFTAR PUSTAKA}

Ahmadi. 2012. Pemberian Probiotik Dalam Pakan Terhadap Pertumbuhan Lele Sangkuriang (Clarias gariepinus)Pada Pendederan II.JPB Perikanan, 3(4):99107.

Cruz, P. M., A.L. Ibanez, O.A.M Hermosillo and H.C.R. Saad. 2012. Use of Probiotic in Aquaculture. ISRN Microbiology, doi: 10. 5402/2012/1916845. 
Direktorat Jenderal Perikanan Budidaya. 2004. Petunjuk Teknis Budidaya Udang Vannamei (Litopenaeus vannamei) Intensif yangBerkelanjutan. BalaiBesar PengembanganBudidaya Air Payau. Departemen Kelautan danPerikanan. Jepara.

Effendie, M.I. 1979. Biologi Perikanan.Yayasan Pustaka Nusantama.163 halaman.

Elumalai, M. Antunes C., Guihernio L.2013. Effects of single metalsand selected enzymes ofcarcinus maens Water, Air. AndSoil Pollution. 141 (1-4); 273-280

Hariati, A. M. 1989. Makanan Ikan. UNIBRAW /LUW / Fishries Product UniversitasHeemstra, P.C. and J.E. Randall. 1993.Groupers of The World. FAO SpeciesCataloque. Food and Agriculture.

Irianto, A. 2003.Probiotik Akuakultur.Gadjah Mada University Pess.Yogyakarta.

Irianto, A. 2007. PotensiMikroorganisme: DiatasLangit Ada Langit.RingkasanOrasi Ilmiah diFakultas Biologi universitasJendral Sudirman Tanggal 12Mei. 125 halaman.

Minggawati, Infa dan Saptono. 2012. Parameter Kualitas Air untuk Budidaya Ikan Patin (Pangasius pangasius) di Karamba Sungai Kahayan, Kota Palangka Raya. Jurnal Ilmu Hewan Tropika. Vol. 1 (1)

Mulyadi, A. E. 2011 dalam Latifah, A. 2016. Pengaruh Pemberian Probiotik Dengan Berbagai Dosis BerbedaUntuk Meningkatkan Pertumbuhan Lele Dumbo (Clarias gariepinus).Skripsi. Universitas Airlangga. Surabaya.

Mudjiman, A. 2004.Makanan Ikan. Penerbit Penebar Swadaya. Jakarta. 116 halaman.

Najiyati, S. 2003. Memelihara Lele Dumbo di Kolam Taman. Penebar Swadaya. Jakarta. 35 - 48 halaman.

Nuraeni. 2012. Pengaruh Pemberian Pakan Tambahan Limbah Ikan Tongkol Terhadap Pertumbuhan Ikan Lele Dumbo (Clarias gariepinus, Burchell 1822).FKIP UNPAK. Bogor.

Nurhayati, 2014.Perkembangan enzim pencernaan dan pertumbuhan larva ikan lele dumbo (Clarias gariepinus Burchell 1822) yang diberi kombinasi cacing sutradan pakan buatan. Jurnal Iktiologi Indonesia, 14(3):167-178.

Parinduri, A. 2015.Pengaruh Penambahan Probiotik Pada PakanTerhadap Pertumbuhan DanKonversi Pakanikan Patin(Pangasius hypopthalmus), Skripsi. Program Studi Manajemen Sumberdaya Perairan,Fakultas Pertanian, UniversitasSumatera Utara.Sumatera Utara.

Ramadhan, M. D. R. 2008. Evaluasi Mutu Protein Secara Biologis Daging yang Difermentasi Lactobacillus plantarum, Skripsi. Program Studi Teknologi Hasil Ternak Fakultas Perternakan, IPB : Bogor.

Rostini, I. 2007. Peran Bakteri Asam Laktat (Lactobacillus Plantarum) Terhadap Masa Simpan Filet Nila Merah Pada Suhu Rendah. Fakultas Perikanan dan Ilmu Kelautan. Unpad: Jatinangor.

Sopha, S.2015. Pengaruh Suptitusi Parsial Tepung Ikan Dengan Tepung Tulang Terhadap Pertumbuhan Ikan Lele Sangkuriang (Clarias gariepinus). Jurnal Rekayasa Dan Teknologi Budidaya Perairan. Vol 3

Widarjono, A. 2015. Statistika Terapan Dengan Excel dan SPSS. UPP STIM YKPN. Yogyakarta. 340 halaman.

Wiranata. 2016. Padat tebar optimal pada budidaya lele (Clarias gariepinus, Burchell) denganSistem Bioflok. Skripsi.Fakultas Teknobiologi : Yogyakarta. 